\title{
Correction to: Contraception for married adolescents (15-19 years) in India: insights from the National Family Health Survey-4 (NFHS-4)
}

Ijyaa Singh ${ }^{1^{*}} \mathbb{D}$, Ankita Shukla ${ }^{2}$, Jissa Vinoda Thulaseedharan ${ }^{1}$ and Gurpreet Singh ${ }^{1}$

\section{Correction to: Reproductive Health (2021) 18:253} https://doi.org/10.1186/s12978-021-01310-9

After publication of this article [1], it was reported that in Table 3, heading "Health care worker contacted in the past 3 months", the confidence interval $(1.21,2.73)$ should have read $(0.86,1.33)$.

The original article [1] has been updated.

\section{Author details}

${ }^{1}$ Achutha Menon Centre for Health Science Studies (AMCHSS), Sree Chitra Tirunal Institute for Medical Sciences and Technology, Trivandrum, Kerala, India. ${ }^{2}$ Population Council, New Delhi, India.

Published online: 28 February 2022

\section{Reference}

1. Singh I, Shukla A, Thulaseedharan JV, Singh G. Contraception for married adolescents (15-19 years) in India: insights from the National Family Health Survey-4 (NFHS-4). Reprod Health. 2021;18:253. https://doi.org/10. 1186/s12978-021-01310-9.

\section{Publisher's Note}

Springer Nature remains neutral with regard to jurisdictional claims in published maps and institutional affiliations.

*Correspondence: ijyaasingh2@gmail.com

${ }^{1}$ Achutha Menon Centre for Health Science Studies (AMCHSS), Sree

Chitra Tirunal Institute for Medical Sciences and Technology, Trivandrum, Kerala, India

Full list of author information is available at the end of the article original author(s) and the source, provide a link to the Creative Commons licence, and indicate if changes were made. The images or other third party material in this article are included in the article's Creative Commons licence, unless indicated otherwise in a credit line to the material. If material is not included in the article's Creative Commons licence and your intended use is not permitted by statutory regulation or exceeds the permitted use, you will need to obtain permission directly from the copyright holder. To view a copy of this licence, visit http://creativecommons.org/licenses/by/4.0/. The Creative Commons Public Domain Dedication waiver (http://creativecommons.org/publicdomain/zero/1.0/) applies to the data made available in this article, unless otherwise stated in a credit line to the data. 